Sign Systems Studies 33.2, 2005

\title{
Hints and guesses: Legal modes of semio-logical reasoning
}

\author{
Dinda L. Gorlée \\ Van Alkemadelaan 806, NL-2597 BC \\ The Hague, The Netherlands \\ e-mail: gorlee@xs4all.nl
}

\begin{abstract}
Legal semiotics is an internationally proliferated subfield of general semiotics. The three-step principles of Peirce's semiotic logic are the three leading categories: firstness, secondness and thirdness, grounded on the reverse principles of logic: deduction, induction and - Peirce's discovery abduction. Neither induction nor abduction can provide a weaker truth claim than deduction. Abduction occurs in intuitive conclusions regarding the possibility of backward reasoning, contrary to the system of law. Civil-law cultures possess an abstract deductive orientation, governed by the rigidity of previous written law, whereas the actual fragility of a common-law system with cases and precedents inclines to induction, orienting its habituality (habits) in moral time and space. Customary law gives credit to abductive values: relevant sentiments, beliefs and propositions are upgraded to valid reasoning. The decision-making by U.S. case law and English common-law is characterized as decision law with abductive undertones.
\end{abstract}

\section{Inquiry of analysis: Holmes and Peirce}

The term "logic" was understood by Charles Sanders Peirce (18391914) in two senses: "In its narrow sense, it is the science of the necessary conditions of the attainment of truth" but in "its broader sense, it is the science of the necessary laws of thought, or, still better (thought always taking place by means of signs), it is general semeiotic, treating not merely of truth, but also of the general conditions of signs being signs" ( $C P: 1.444)$. Metaphorically, the first sense is viewed as "cold", the second as both "cold" and "hot"; semiotically, Peirce spoke of "hard" and "soft" in his crucial article "How to make 
our ideas clear" $(C P: 5.403=W: 3: 266 \mathrm{f}$.). If we discuss the language of the decisions and language of the law, we deal with written thought-signs, sign-events and sign-phenomena from a legal viewpoint, where the law is said to "treat of second intentions as applied to first" (CP: 1.559) and thereby dealing with semiotics and its finding and judging the facts of interpretation of experience and rules. Peirce stated that "the rules of logic hold good of any symbols, of those that are written or spoken as well as those which are thought" (CP: 1.559).

Legal semiotics discovers and analyzes fact and law in written laws, proceedings, tribunals, judges, and verdicts, bringing facts and law together "with a concern for procedure, a concern for rules, and a concern for legal categories" (Lempert 1988: 161, see 162-165). Legal semiotics embraces both the broad and the narrow sense of the "formal conditions of the truth of symbols" $(C P: 1.559)$ where lawful and unlawful conclusions, exchanged between the parties, are derived from premises with varying success, as will be discussed in this article. Following Weston's division into a various subclasses or subregisters, the language of the law is "really a blanket term covering several varieties or subregisters" (Weston 1991: 14) in the following legal interactions:

(1) professional discussions between sollicitor or barrister and client (mode: spoken; functions: e.g. exposition, advice, sympathy; formality: neutral/formal);

(2) professional discussions between legal practitioners among themselves (mode: spoken; functions: various; formality: usually neutral or informal, maybe formal between junior and senior);

(3) judge giving judgment in court (mode: spoken or written-to-bespoken; functions: information, exposition, possibly literary; formality: formal);

(4) advocate pleading in court (mode: spoken; functions: persuation, exposition, possibly flattery, provocation, etc.; formality: neutral/ formal);

(5) legislation (mode: written; functions: regulation of conduct, injunction, archaism, etc.; formality: very formal). (Weston 1991: 14-15)

The kaleidoscopic variety in mode, formality, and functions of legal speech includes legal language in activities such as legislation, 
courtroom activities, lawyer-client communications, legal literature, etc. influencing and determining the sense of the linguistic genre and style used by individuals of a particular legal status in the actual exercise of their role as such.

The concept and the external sign of the semiotics of law has no Peircean roots. Peirce, a polymath scientist, was no lawyer, but between 1870 and 1874 Peirce had jurists-friends in the Metaphysical Club, particularly the famous forefather of American law, Judge Oliver Wendell Holmes, jr. (1841-1935). ${ }^{1}$ Holmes's legal theory aimed to provide a general view of the common law, offering a pragmatic account of criminal punishment and civil liability (Millar 1975, Valauri 1991). In his efforts to redact the new proposal in The Common Law (1881), his main oeuvre, Holmes was probably influenced by Peirce's standards of the 1870 s, when Peirce wrote the celebrated articles "The Fixation of Belief" $(C P: 5.358-5.387=W: 3$ : 242-257) and "How To Make Our Ideas Clear" (CP: 5.388-5.410= $W$ : 3: 257-276; see Fisch 1986a: xxix-xxxvii) (in both articles in $W$ : 3 , the footnotes of CP, written later, are excluded). Whereas Peirce's standards go back to the underlying properties of the subject's behavior and then grow into the duty and obligation to the community, Holmes's legal rules are equally public (not private) and external (not internal) habits. The shifting senses of fundamental terms in our real world correspond to the changeable, moral or ethical properties of legal acts which eventually tend to develop order out of the "chaos" of legal behavior. This evolutionary change, advocated by Holmes, is the touchstone of later jurisprudence in common law, and agrees with ideas from Peircean semiotics. The community makes contact with social reality, but also distorts reality by the circumstances of the legal action (on reality and human "reality", see Gorlée 2004: 146, 224-225 note 1$)$.

In contrast to "European" or Continental law, there is no general theory of liability in American law. The court needs to assess each specific case to evaluate which kinds of "bond of necessity exist between the wrongdoer and the remedy of the wrong" (Black's 1999: 925). The shifting and interactive senses of observation and

See Fisch (1986a, 1986b) and Menand (2001) for the vital account of the intellectual meetings of Holmes and Peirce in the company of William James (1842-1920), John Dewey (1859-1952, who was twenty years younger than Peirce), and other associates of the Metaphysical Club. 
experience (viewed in Peirce's view, the semiotic meanings) indicate different modes of reasoning, discussed by Holmes who asserted in the beginning of The Common Law that "The life of the law has not been logic: it has been experience", adding that the law finds its philosophy in "consideration of what is expedient for the community concerned" (after Menand 2001: 341). Following Holmes's doctrine of legal obligation or debts to pay to another or to society, enforceable negligence can be relevant or irrelevant, fixed or contingent (Gorlée 1999), depending on which doctrine of laws applies. To justify the nature of the criminal responsibility, Holmes's theory of legal liability requires the presence of a will before the act (or its omission: a defect of will). Holmes stated in The Common Law (1881) that "an act implies a choice, and that is felt to be impolitic and unjust to make a man answerable for harm, unless he might have chosen otherwise" (Holmes 1963: 46). This will to bridge a breach of trust does not come from valid logic but, rather, is a re-evaluation of the concept of Holmes's "felt necessities" (Holmes 1881: I, 35; see Pohlman 1984: 212). Holmes referred here to extralegal concepts: experience and feeling, integrated into legal decision-making, which will be discussed in this article.

According to the pragmatic interpretation, introduced by Peirce, law is created by single jurists (subjective law) but with its action belongs to communal property (objective law). Advised by observation and experience, law is created, as Holmes stated in the beginning of The Common Law:

The life of the law has not been logic: it has been experience. The felt necessities of the time, the prevalent moral and political theories, intuitions of public policy, avowed or unconscious, even the prejudices which judges share with their fellow-men, have had a good deal more to do than the syllogism in determining the rules by which men should be governed. (Holmes 1881: I, 35, after Schwartz 1993: 191)

These words begin a new area of jurisprudence with "new logic", moving from the traditional process of deduction towards induction and some grounds of abduction - focusing on the terminology of nonrational and irrational elements of human reasoning. Holmes used new and radical words in legal science: "experience", "expediency", "necessity", and "life". From Holmes's proposal, the values of the experiences of the nation affect and stimulate further developments in 
the nation. These values are phrased in the interactive framework of Peirce's laws of inference (discussed in this article). To build standards and legislation in American law, Holmes could derive from Peirce's pragmatic principles and his teleology of descriptive and analytical semiotics, and his ideas regarding legal realism. Peirce's teleology can be applied to Holmes's empirical legal science concerned with the "real" facts of the legal sign-situation, connecting the legal rules and standards as a necessarily objective reservoir of observation and experience of the community (Fisch 1986b).

The experience and the logic of a Peirce-linked inquiry in legal semiotics are beginning to influence legal semiotics and its future developments, which has become now an internationally proliferated subfield. The former International Association for the Semiotics of Law, now replaced by the International Roundtables for the Semiotics of Law, do mainly follow the semiotic school of Paris regarding Greimassian semiotics (Algirdas Julien Greimas 1917-1992). This legal direction follows the tradition of Course of General Linguistics by Ferdinand de Saussure (1857-1913), in which comparative methodology, verification-falsification process, diachronic and synchronic approaches, and the semiotic narrativity are deployed. The Peircean inquiry on legal semiotics was the life-work of Roberta Kevelson (1931-1998). She founded the Center for Semiotic Research in Law, Government and Economics at Pennsylvania State University in Reading, Pennsylvania. She considered in her prolific writings on legal semiotics that worldwide law is "really a system of signs types of an iceberg whose bulk is eclipsed but assumed, or known to exist" (Kevelson 1982: 162). The approach to Peirce's legal semiotics is argued in Kevelson's books (1988; 1990; 1991; her articles 1986; 1982; 1993; and other work). Kevelson speaks here about Peirce's acuteness on three semiotic points: the real semiotic definition with inherent sign, inherent and extrinsic object(s), and extrinsic interpretant(s) resting on the philosophical categories, corresponding to the evolutionary inward-and-outward sequence of terms: firstness, secondness, and thirdness - in their semio-logical changes and exchanges. This semiotic tradition including an (in)determinate legal semiosis, will be followed further in this article. 


\section{Peirce's three categories}

Peirce stated that "First is the conception of being or existing independently of anything else; Second is the conception of being relative to, the conception of reaction with, something else; Third is the concept of mediation whereby a first and a second are brought into a relation" $(C P: 6.32)$. Firstness is pure potentiality $(C P: 1.422)$, which is "predominant in the ideas of freshness, life, spontaneity, freedom" (CP: 1.324). Firstness means instantaneous emotion, direct "suchness" of feeling, raising an elementary question with its direct "maybe" (or "maybe not") not dependent to nothing else beyond its own qualitative understanding of the possible meaning of the sign without thought. Firstness is undivided and undividable oneness, where thought is still absent, only the current instantaneous shiver of emotion ran through human life. Secondness is dynamic motion, orienting oneself in time and space, taking one's stand in the moment of "here and now", and maintaining one's moral place over time. Secondness thinks about the discrimination of good and evil of manysided actuality, it sents messages with action and reaction as a response to a stimulus which may cause a change of state from firstness to movement. Thirdness states the set of habits and habit-changing previously formed, which control the changing cognitive activity of human experience with respect to its response to stimulus.

Thirdness (Peirce's symbolicity) involves bringing states of firstness and events of secondness together in a mutual friendship of intellect. Whereas firstness rests on the idea of independence and secondness is the idea of oppositions, thirdness rests on the idea of the complexities of cognitive relationship (CP: 1.297). Among the categorial characters of thirdness are therefore mediation, thought, rules, habits, and law (the latter as general term, but also applied to legal studies) $(C P: 1.345 \mathrm{f}, 1.405 \mathrm{f})$. These symbolic-cultural terms are always infinite, borderless, and never fixed. Peirce argues the changing characters of thirdness, changing according to different convenience in human "reality". State of feeling can be changed, the (re)action can also be changed, and there we deal with a new sign and a new meaning. Semiosis or forceful sign-activity changes with time and space, and entertains successfully new doubts, new beliefs, and new persuasions. Under duress of moral time and space a new habit formation cycle is generated to fit back into the renewed semiotic 
process. This relationship was experienced by Judge Holmes in his day when he defined liability not as our right, power nor liberty, but as its own "vinculum juris [which] is not one of mere duty or obligation; it pertains not to the sphere of ought but to that of must" (John Salmond quoted in Black's 1999: 925, emphasis as in the original) as its own symbol in its own social, psychological, economic, ethical elements of experience, functioning in a changing legal semiosphere.

In Peirce's categorial scheme we characterize the final category of thirdness, semiotic symbolicity, referring to the plural variety of disciplinary terms used in general inquiry: representation, mediation, branching, cognition, synthetic consciousness, theory, processuality, habits, reason, transuasion, transaction, betweenness, continuity, regularity, evolution, as well as God. In the bizarre juxtaposition bridged by Peirce's thirdness, we perceive the generality of the law, as well as the language of the law. The different perspectives of rational thirdness can be explored from different angles chosen in the discussion of rational, nonrational and irrational elements of legal semiotics to create a human experience, the sociological and psychological secondness of life. Peirce's categoriology includes thirdness, but thirdness appears preceded by secondness and firstness, and includes the symbiosis between three categories. Semiosis (in the overall terms of thirdness) organizes and integrates the data of human experience: in legal terms, the human mind makes the formless universe into liveable objects and events, that is, it creates a structured dynamic, and never static, organ of law and lawfulness. The function of legal language is to guide and stimulate inquiry into human "reality", and make "reality" a structured and reasonable medium.

We see this phenomenon of inquiry in the structure and effect of the legal contract (on Peirce's contractuality, see Gorlée 1994: 197223). As contractual agreement between interacting parties the contract implies a value through mutual consent. As third the contract is given a meaning with consequences in human experience: the meaning is not virtual but happens in actual life-experience (including no thirdness but secondness and even firstness). A contract is thereby an interpersonal conception of a bargain, considered as a process of maintaining a synergetic relationship. Peirce's basic entity of a first, the possible sign, the second, the semiotically real but no actually real object(s), and the third, the interpretant(s), roughly the meaning(s) of the sign-event, are all based on Peirce's categorial methodology, as 
applied to law. Peirce's laboratory inquiry, solved by experiments leading to consistent, common-sense results in reality illustrates the collective habit in three interactive phases (discussed in Gorlée 2004).

\section{Semio-legal logic and truth}

Legal logic and therefore legal thinking and language consist not of monolog, but of a secret or hidden dialog pronounced in silent and/or outspoken words of commands, geared toward a question/answer relation. The verbal speech creates what Peirce called the "fixation of belief" (CP: $5.358 \mathrm{ff}=W: 3: 242 \mathrm{ff})$ and leads towards a performance in a future time. In Peirce's days, it inspired Holmes's prediction theory of law (Fisch 1986a; 1986b) involving a choice and possibility, changing from age to age. Peirce's theory of rational knowledge formation signifies a justified emendation of future actions. Legalese (the language of the law) has therefore a changing, contractual basis, corresponding as all semiotic processes to language as symbolic thirds, but based on cultural and linguistic signs. Legal logic offers legal acts, but is generally a social theory of logic dealing with complex linguistic signs - doctrines in both words, paraphrases, and definitions rooted in thought-signs, and interpreted variously by a community of inquirers, appealed to today and in the future. In semiotic terminology, the doctrines have become non-doctrines and are called vocabulary, phraseology, and textology (Gorlée 2004: 159, 197f). The legal parties (Peirce's inquirers) are not flesh-and-blood individuals but are either skilled legal brains - those of a legally trained individual - or unskilled legal brains - of legal illiterates, lacking formal training in legal studies, ostensibly fated to be a legally silent majority of potential "victims" of the law (Boasson 1966: 65ff; Gorlée 1999: 246).

Legal reasoning rests on a relatively closed set of legal premises that can be known and argued by human individuals with legal training. It is both an open and a closed system based on previous logical thought (thirdness), yet the system is infinite and has no finite, closet set of legal premises. The conclusions - or interpretant(s) of the legal inference - remain open and present unpredictable possibilities. This is the legal openness in Peirce's semiotic "dialogism" (CP: 3.172, 3.197, 3.623), meaning that the decisions and choice in 
logical thought can give both predictable and impredictable senses of the interpretive results: namely, either adding to the law system or even jeopardizing it. This is contrary to the desired closeness of legal language, and would seem a negative perspective on the effects of legal language itself. It is also a positive point of view, because it produces relative openness for interpreters to consider and evolve new developments inside the present data. In this way, the legal rhetoric generates further with time and space into a legal pluralism, still rooted in the target: spontaneous order in society, as is the requirements in Peirce's final concept of community.

If we study legal semiotics according to Peirce's sign theory, thought-signs are indeed not entirely rational and logical. They also embrace practical and intuitive knowledge, constantly trying to integrate them into reason. Legal logic and language (thirdness) then attempts to integrate signs of fact or experience (secondness), based on signs of feeling or emotion (firstness). The fact and feeling are, however, invisible but still present in the discourse referring to absent - that is deleted, neglected, or abandoned - outside items. Reason is therefore relatively present in legalese, a reason that is still fixed and definite but despite its generality embedded in abductive thought. The practical feeling brings vagueness to reason, but eventually brings it eventually closer to the reality of truth (also called certainty within philosophy, as opposed to uncertainty) as humans like to live and survive by it. Peirce stated that

The purpose of every sign is to express "fact", and by being joined with other signs, to approach as nearly as possible to determing an interpretant which would be the perfect Truth, the absolute Truth, and a such (at least, we may use this language) would be the very Universe. (NEM: 4: 239, Peirce's emphasis)

Yet legal truth does not exist, since cases after final ruling (verdict) can be appealed to a higher court and in this new proceeding for reversal are taken anew with the same of different circumstances. It means that "the truth, the whole truth, and nothing but the truth" becomes a degree of non-truth.

Language, including legal language, is basically a third and formal, but engaged in the working process of its multiple "drive for reference" (Mertz, Weissbourd 1985: 262, 268, 276, 283). Language has a truth but has no absolute truth value. Given, moreover, that its 
right thinking "depends unconditionally upon the relation of the fact inferred to the facts posited in the premisses" $(C P: 5.270=W: 2: 215)$, its truth is wholly a function of this relation, so that "as long as the premisses are true, however other facts may be, the conclusions will be true" $(C P: 5.271=W: 2: 215)$. For the argument here it is important that all the modes of reasoning, even truth-giving deduction, which is Peirce's first symbolic sign leading to valid mechanical reasoning, does not question the validity of the hypotheses contained in its own premises; instead, it is simply taken for granted that they are correct because they represent our whole knowledge of the matter.

\section{Three modes of reasoning}

Reasoning is the logical desire to reach the unknown through the known, organized by Peirce in his semio-logical method of inquiry (Rescher 1978), linked to the classical logical principles but transposed in other working forms (abstract and concrete shapes) in order to grasp and drive the dynamics of thought. Scientific inquiry is always inspired by intellectual curiosity and is based on reasonable thirds (thought-signs, conclusions) which need to have, however, seconds and firsts involved in them. A phenomenon, event, or fact, is interesting to a certain investigator, and becomes for him/her a semiotic sign-phenomenon challenging his/her inquirer's ingenuity. In order to explain and analyze the sign in its historical and present facts, and to make predictions about its future nature or behaviour, the signphenomenon is carefully seen, observed, and reflected upon. Man-asa-scientist seeks to enhance the scientific value and the validity of the conclusion(s) of the laboratory inquiry, by adopting a policy in right thinking which is hoped to minimize the risk of subjectivity and provide maximum objectivity. To achieve this purpose of seeking truth, the data obtained of the sign-phenomenon are grounded by inferential reasoning. This is the three-step methods of reasoning, which is expected to yield true conclusions now or eventually.

The three-step principles fits of logic was traditionally either deductive or inductive reasoning. Peirce revolutionized the traditional dichotomy which he expanded and re-defined as a trichotomy by including his abduction (1867). Peirce's decision-making distinguished between explicatory (or analytic) reasoning — deduction - and 
ampliative (or synthetic) reasoning — induction and Peirce's abduction. Explicatory (or analytic) reasoning corresponds to deductive inference, like in this example taken from Peirce's beanbag:

Rule

Case

- Result
All the beans from this bag are white.

These beans are from this bag.

These beans are white. $(C P: 2.623=W: 3$ :

325)

It simply substitutes for the facts presented in the premiss, what is implicit in them. Like inference from the known whole to the parts, it does not draw upon the unknown or the partially unknown. This makes deduction the only form of "necessary" (that is, explicatory) reasoning to reach truth in itself, since deduction forecloses critical (re)examination and (re)evaluation of its premises and does not engage in the introduction of new insights, nor in the rejection of hypotheses already adopted.

On the other hand, non-inductive (ampliative or synthetic) reasoning does not lead to necessary conclusions, but to conclusions which are probable or merely plausible. In Peirce's words, "Deduction proves that something must be", and "Induction shows that something actually is operative", yet "Abduction merely suggests that something may be" (CP: 5.171, Peirce's emphasis). Induction — the traditional reasoning about signs in reality - as well as abduction (also called hypothesis or retroduction by its "inventor" Peirce himself) — which is logic from the known parts to the unknown whole - are temporary guidepost to logic. Induction and abduction are "statistical inference" according to Peirce, who explained: "Out of a bag of black and white beans I take a few handfuls, and from this sample I can judge approximately the proportions of black and white in the whole" $(C P$ : $5.349=W: 2: 268$ ).

The shift between a legal monolog (meaning a question: law, writ of summons, court decision, will, testimony, plea, oath, bank statement) to the intended dialog (meaning a answer and question relation: a request for advice, marriage settlement, interrogation report, police inquiry, cross-examination) requires the removal of explicatory arguments. Instead of arguing a verbal legal text we argue what is implied in it: decisions, commands or orders, and rules (Friedman 1977: 24). In a court case, we deal with mixed cases including authorative statements. A court case is provided with 
defense, cross-examining a witness, a jury verdict, and similar items. In a court case, deduction is replaced by ampliative, or synthetic, arguments. Inductivist character of legal reasoning rests on what "actually is" (CP: 5.171), Peirce's signs of secondness:

Rule

These beans are from this bag.

Case

- Result These beans are white.

All the beans from this bag are white. $(C P: 2.623=$ $W: 3: 325)$

Inductive inference gives "a course of experimental investigation" $(C P: 5.168)$. It assumes that "what is true for a whole collection is true of a number of instances taken from it at random" $(C P: 5.275=W: 2$ : 217). Induction is, as said, a statistical argument, the sign points outside itself to the object referred to; it is a second, giving "a fragment torn away from the object, the two in their Existence being one whole or a part of such whole" (CP: 2.230). Induction establishes a clear cause-consequence relation between premiss and conclusion (between sign and interpretant) which requires the investigator to follow it "blindly". There can be no absolute certainty in induction, because the inquirer, spurred by intellectual curiosity $(C P: 5.584)$ is in fact making predictions and thereby judging the unseen by the seen. New knowledge is inferred by extrapolating it from actual fact toward the unknown. Induction is therefore a "practical truth" (CP: 6.527), bringing the inquirer halfway the path which, in the Peircean view, must eventually lead him or her from interrogation and doubt to certainty and truth.

This classification can be applied to the two prominent systems of law and to legal reasoning in the Western world, the latter now integrating the emerging ex-Communist legal world. Civil-law (originally the Latin jus civile) cultures possess a deductive orientation, governed by written laws, statutes, and constitutions imposed by the state through a parliamentary procedure (deriving from the sovereign), while a common-law system (derived from the Old French commen ley) is in itself "inarticulate until it is expressed in a judgment" (Patrick Devlin quoted in Black's 1999: 270). Common law consists of the interpretation of the judges whose formal decisions form precedents in respect of succeeding cases. Common law is a body of rules concerned with the authority of cases and precedents. The statutary law inclines to reasoning according to inductive thought. 
Judicial decisions can overrule - that is: change - its binding codes in new statutes according to changing standards of time and space. By this strategy or power involving the strict judicial "oracles of the law" (Holmes 1897: 457), the judges leave a legacy to future ages.

Civil law emphasize a moderate standpoint of legal positivism and is ruled a judicial decisions rather than legislations. Civil law tends to give more prominence to the imperative idea to reasoning by a lawmaking organ than common law with their more legal realist and empirical orientations, is inclined to do. European law has a strong rigidity and stability, and offers through its written form some resistance to manipulation. The repeatable regularity in continental law is the conclusion of its deductive habit: its real logical syllogism goes from legal ideas to real ideas. Probable reasoning is the inductive syllogism, which moves from ideas to things, the latter are material (extralegal) things existing in human experience.

Anglo-American legal theory is today a mixture of two legal elements, not considering so-called "equity" (a third system of English law, responding to ideas of natural justice, now part of common law; see Williams 1982: 25-29, Black's 1999: 560): (1) the so-called common law, judicial law based on court decisions within the legal framework of cases and precedents, differing fundamentally from Roman law (filtered through Napoleon code) which governs most Western legal systems, and (2) statute written law, which is written law based on previously codified law. Common law, deriving its force through the rigidity of its reasonableness and truth, is more adaptable than the actual fragility of the fixed form of statute law, oriented to the changing needs to society. Peirce would call common law a system of habituality, a habit-transforming strategy, where new habits are constantly enforced (and denied). New habituality ensures a way to avoid conservatism and create new meanings in the law. Both statute law and common law are in fact rule-forming institutionalization rules and eventually — or as Peirce wrote: in the long run - proceed from induction (seconds) to deduction (thirds). 


\section{Abductive beliefs}

Every inquiry, scientific and practical, needs to formulate and adopt certain hypotheses on which to further build the argumentation. It uses instinctive reasoning, or hypotheses - also called abduction by the term's discoverer, Peirce himself [see Gorlée 1996 (English version), 2000 (rev. German version), 2004: 114-132 (2nd rev. English version)]. In the abductive inference, we catch a new "case from a rule and result" (CP: $2.623=W: 3: 325$, Peirce's emphasis). Peirce added: "On the table there is a handful of white beans; and, after some searching, I find one of the bags contains white beans only. I at once infer as probability, or as a fair guess, that this handful was taken out of that bag" $(C P: 2.623=W: 3: 325)$ :
Rule
All the beans from this bag are white.
Case These beans are white.
- Result These beans are from this bag. $(C P: 2.623=W: 3: 326)$

Abductive mannerisms are contrasted with deduction and induction, and are backward reasoning. Abduction is based on hunches and guessing, and the emotional overtones build intuitive opportunities stating "may" and "maybe not". This gives through the abductive experience, new surprises and information.

Of the three modes of reasoning, abduction is the only to "open up new ground" (NEM: 3: 206) and to introduce novelty into the intellectual (or pseudo-intellectual) inquiry. Induction moves from ideas to things, whereas abduction is a reverse operation: abductive syllogism moves from things to ideas, from outside to inside. Inquiry seems to start from catching the inquirer's flavors, tastes, and expectancies until it reaches his or her hypotheses on the case. Weak as the absolute truth value of abduction may be and in fact is - at least when compared to the probative force of its stronger counterparts: deduction and induction - it is nevertheless the creative force breathing the air of originality into what would otherwise be a "reasonable" $(C P: 5.174)$ but utterly rationalistic and, thereby, lifeless process.

Peirce relabeled a mode of thought, which for all his conjectural tentativeness, was often plausible. It suggests more than gratuitous guesswork, and is the lightning flash breaking through logical analysis to shed light on the underlying instinctual feeling. The tentative 
explanation is iconically prefigured in the premises. The first premiss describes what the beans must be like to qualify as beans from this bag. The interpretant (the legal conclusion) of an abduction is an icon, here whiteness. The rest is guessing based on rational instinct, creating feeling. It is believed that abduction looks somehow into the unseen universe and tries to make some hypothesis concerning it. Abduction corresponds to Peirce's firstness, which is "represented" by the unthinkable (but feelable) iconic image, since it seems to stand for its object in virtue of its analogy with it.

The abductive overtones of logical reasoning is unsuited to legal systems and legal acts, because its judgment gives no certainty: the decisions are of an emotional nature and happen in the form of intuitive perceptions: "It seems to me that ..." Abductive judgments offer personal values and build the signs to acquire their genuine and collective meaning(s) through self-control and settling of doubts within, firstly, induction and subsequently, deduction. This is the evolution of Peirce's "fixation of belief" (mentioned before) and abductive beliefs are the first and essential steps further on the way toward final reasonableness. Abduction is not included in the cognitive laws and dispositions (such as common law and statute law, discussed above). Abductive forms are not (or not yet) inquiry but, rather, forms of inchoate questioning out of which legal discourses may possibly emerge in the long run of history. We speak here about the emotive, religious or political values, integrated into explicit law, but a "hidden" but real abductive rationale in common law and statute law, where feelings are mentioned or, as the case may be, unmentioned. Take, for instance, Peirce's and Holmes's "felt necessities", the social and individual intuitions, which are the seed of every growth of law. Take liability as a legal act, a human experience which implies a human choice, where man (woman) decides to make himself (or herself) answerable for harm or no.

The discovery of acceptable premises in abductive backward reasoning clearly occurs in non-written law, transmitted via oral tradition and through the power of memory. Non-written law includes religious-based or political-based sentiments, beliefs, or propositions (following the order of Peirce's categories). In European law systems we find the system of the law in four progressive terms: firstly in laws, secondly in treaties, thirdly in jurisdiction and fourthly in customary law. Laws belong primarily to deduction; treaties have a deductive- 
inductive character; jurisdiction is primarily an upgraded inductive character. The latter, customary law is unwritten law, established by long use of local rules, which is still considered as a valid right affecting openly and clearly the inhabitants of districts or regions, and legally affecting the outsiders. These traditional rural rights, and their acts, perform a repeatable tendency toward a regularity in the existing legal situation. The local rules are probably the historical remains of traditional customs of trade and commerce in provincial regions, and do not come from central authority. Customary law gives credit to abductive values: relevant sentiments, beliefs and propositions are upgraded from a sense of customary rights to valid thought, probably due to practical and ethical circumstances in culture, geography, and climate. An example would be the Norwegian custom of dugnad ("community self-help" and "joint efforts"), meaning the voluntary and cooperative work carried by members of clubs, schools, and organizations for the purpose of helping the neighbours living in the isolated, mountainous countrylife in Norway. Despite coming from personal witnesses (notaries, police, noblemen, counselors, lay judges, elders, and wise men and women) testifying to the certain real existence of customary law, old customs have gained the status of written law in a particular area and have acquired a common acceptance.

Legal examples can be drawn from commerce in agriculture, cattle raising, fishery, forestry, and associate branches. In British case of law, in Wilson $v$ Willes (1806), the tenants of a manor claimed the customary right to take as much turf as they needed for their lawns from the manorial commons. This was in legal terms held to be too vague, since there appeared to be no limit to the amount of turf which could be taken. In Mills $v$ Corporation of Colchester (1867), it was held that a customary right to fish had no legal force where the right had always depended on the granting of a licence, even though such licences had traditionally been granted to local people on request. In (inter)national business cases, customary law mostly provides for irreconciliable grounds of decision-making. In a modern case, North and South Trust Co $v$ Berkeley (1971), goods transported from Buenos Aires arriving in Asunción arrived in shortage. To settle the case of claim, the insurance with Lloyd's was inspected by the agent acting here for both parties. This long standing practice of Lloyd's inspecting and defending both policies of insurance - raised issues of 
impartiality and bad faith (in legal terms, fraud and non-disclosure). The custody of customary law used by insurance brokers worldwide remained unsuccessful in the Courts. Customary law is only exercised as of right when it is a clear and certain practice. The judicial decision in North and South Trust Co $v$ Berkeley (1971) uses independent asessors to inspect the case for both parties; clearly breaking away from customary prerogatives or "privileges" toward the principles of valid morality of commercial law.

Enforceable law in Western and non-Western countries is also due to abductive differences in historical and cultural facts and phenomena. If we perceive the current classification of legal systems, which is neither biological nor geographical, but dogmatic and undogmatic (breaking out of the discussed pattern of inductive common-law and deductive statute law), we encounter a large variety of legal systems in which we see the triadic symbiosis of abductive, inductive, and deductive principles maintaining a synergetic relationship with one predominant element and the two subyacent elements. When the abductive element is the dominant idea, the result may be halfconscious and undeveloped, and hence a false problem-solving method - called "degeneracy" in Peirce's terminology; see further in this article and discussed in Gorlée (1990). The target of this process is, however, the formation of evolutionary law systems - Peirce's valid thirds - as right thinking now and in the future.

Practical examples would be like the disappearing socialist law which sought to transform the legal community in accordance with the original Marxist-Leninist school of thought, based on state government, a classless society, and no right to individual property, since the right of legal rights (capital production) is replaced by common ownership by the state; Islamic law - based on doctrines of obligations called Sunna giving prophetic pronouncements and rules from Saria and Koran in which religion and law are one; the law system in Israel - a mixture of common law and the Hebrew Bible, the Torah, plus commentaries by rabbis plus the commentaries made of the Five Books of Moses, the Misnah and Talmud; the African law systems - based on principles of animism embodied in totems, shamans, idols, and awes of ancestor worship; as well as other mixed law systems in which room for intuitive judgments plays a legal role. Varieties of such archaic customs are also the main characteristics of the law of tribes inspired by African metaphysical thinking (abstracted 
from the original French-oriented, and English-linked, statute law) as well as the "primitive" (but sophisticated) law of Saami people (formerly called Lapps), Australian aborigines, and Indian populations in Brazil, cultivating their own spiritual or sacred initial beliefs which are regarded to bring reasonableness, against the struggle with the authority. Local customs are an active juridical layer chiefly but safely spreading under the enforceable rights of the Norwegian, Australian, Brazilian, etc. official laws, where political and religious practices are considered a trusted belief of the entire national community.

\section{Abductive sign-action}

Peirce, not a trained lawyer but a talented thinker, logician and scientist, did not expand the abductive idea for legal purposes, and its significance will require some interpretative extrapolation. In his reviews in The Nation (1869-1908), Peirce reviewed scientific and philosophical literature, and could use his reviews for exploring some intricate problems in many areas and disciplines, which in the 19th century were not so hyperspecialized as universities and colleges are today: a stroke of good fortune for the interdisciplinary (or transdisciplinary) semiotician then and today. In a hidden paragraph (written in 1901), Peirce editorialized in his essentially negative, even alarmist review on the book on Ethics: Descriptive and Explanatory written by Sidney Edward Mezes, professor of philosophy at the University of Texas (CTN: 2: 149), as follows:

A judge, let us suppose, has brought before him a case in which a case in which a man has suffered injury for which he claims damages of another. Whether damages ought to be paid in such a case is often, as we know, a delicate and puzzling question. We will follow Professor Mezes in using a much too simple illlustration, which ought to puzzle nobody. "Take", he says, "the case where A's cattle break out of their enclosure, in spite of A's having used all the care he reasonably could have used, or learned to use, and could learn to use, and destroy B's valuable crop in an adjoining field". This case (or rather another far more difficult) puzzles the judge, and he takes it under advisement. He naturally looks into the works on ethics, and, finding nothing pertinent in modern books, is driven to the scholastic treatises. Now, there is nothing in the whole scholastic logic more justly an object of derision for any modern thinker than its weak confusion of thought in its doctrine of causes; not in that whole doctrine is there any more manifest absurdity than the distinction between a proximate and a 
remote cause. When we meet with an application of it in the scholastic commentary on the Sentences, it stands out as so much more nonsensical than the rest as to be comical; but that anybody should be made to suffer because of any consequence of such metaphysical jargon is outrageous flippancy. Yet it is just this outrage that the judge us driven to commit, or to pretend to commit, because the ethical writers have not expounded right and wrong in a sufficiently luminous and reasonable form.

Professor Mezes follows them. He maintains that A, the owner of the cattle, ought to reimburse B for the injury one by them to his crop, because A is the proximate cause of B's suffering. If he would not follow the decisions of Texas courts as the ultimate evidence concerning right and wrong; he could not fail to see that the real reason why the judge awards damages to $B$ is that to allow a private person to undertake a business humanly sure in the long run to injure his neighbors (and all the more so if he "cannot learn to use" suitable preventive measures), and then allow him to pocket all the profits, and make his neighbors pay for incidental losses, would be to bring himself and his court into public contempt and into no little danger. That was the judge's real reason. But in days gone by (perhaps not yet in Texas) if a judge could decide a case justly, and yet by a process of metaphysical reasoning the less intelligible the better, he was regarded with awe by the vulgar; and that was one motive for his seizing upon that argument when he could get no modern light. (CTN: 3: 51-52, Peirce's emphasis)

It is significant that Peirce's problems in this scholarly review necessarily had to abstract from his own theory of signs and his doctrine of categories, both of which were unfamiliar to the audience of The Nation and unwelcome to the editor (Bernstein 1975; Gorlée 2004: 187, 230). Yet Peirce's example brought to life in his delicately farcical elaboration of the pragmatic adventures of legal ethics, as lessons in legal morality (Gorlée 2004: 187, 230) and approaches himself to Holmes' theory of liability, as described.

A sure sign of semiosis, "a sequence of inferences or a train of thought" ( $C P: 7.583)$, put into deliberation by the judge, words and rewords the action of a legal semiosis - including the triad of a sign, its object, and the interpretant - all of them providing clarity as well as a degree of vagueness to the case. The complex fate of the sign, which consists in Peirce's "puzzling" details or facts of the case, or otherwise requires someone's special attention suggesting it means something other than itself, or something more than itself, thereby inviting, even requiring some further information in the form of new information here, no real but transworded, legal information - about the "real" sign-event. The sign-action still remains indeterminate and uncertain, 
and continues to "puzzle the judge", since two objects determine the sign and what happened to it. One object, the "immediate object" as it is represented by the sign and can be a quality, an existent, or a law $(P W: 33)$. The immediate object is the object "inside" the sign at face value, whereas we also have to deal with the "dynamical object", absent in the immediate object and in the sign, but found in the real context of the sign relation. The dynamical object is "the Object outside the Sign [...]. The Sign must indicate it my a hint; and this hint, or its substance, is the Immediate Object" $(P W: 83)$. The visible and invisible objects are suggested in Peirce's distinction between Peirce's "proximate" and a "remote" cause, both of them determining to blur the process of semiosis — suggested by a "hint". The differences between three interpretants - immediate, dynamical, and final interpretants - join the object in determining the modalities of the circumstances of the primary sign in its histority, but the final effect of the case serves to illustrate a model of precedent cases in Peirce's "luminous and reasonable form". As stated by Ransdell:

There are occasions when the dynamical interpretant - that is, the actually occurring interpretant — of a sign which is the law is not definitely identifiable because the law is to vague in the relevant respect: the facts of the case may be clear enough but the meaning of the law is not, and the judge must, as we say, exercise real judgment in the matter (which is to say that the judge must recognize something as being the relevant dynamical interpretant without benefit of recourse to any ascertainable basis in the immediate interpretant that would justify that recognition). The conscientious judge makes a guess, in effect, at what the final interpretant includes when he or she recognizes something as being a dynamical interpretant of that law at that time relative to that case. But it is the course of future legal interpretation of that law (in courts of appeal, in future juridical practice, and so on) that will determine whether the judge was or was not right in his or her attempt to anticipate the relevant content of the final interpretant - or, as we would ordinarily say, in the attempt to set a precedent that will be honored. (Ransdell 1986: 682-683, Ransdell's emphasis)

The at least partial indeterminacy of the possible meanings of the primary sign makes the sign relation a powerful but fallible instrument of logical discovery of familiar and unfamiliar elements of the facts related to the knowledge of the (un)criminal sign and its contextual meaning. Surprisingly, in the bastion of legal reason, the judge's speculations introduce to deduction and induction a sphere of abduction with hints and guesses, which are self-controlled to 
discipline the rationality of its beliefs and give rise to discussions and debate.

\section{Judicial decisions}

Decision law is seen as "organic" law with a human(ized) meaning (in common and non-legal terminology (Garner 1987: 395). Therefore, judicial decision law will have life and grow in diversity and individuality from outside inwards, and is far from dogmatic, but "skeptical" law. Judicial decisions are "self-multiplied, self-shaping and self-regulating", but with "shades of irritability and sensitivity" (Rottleuthner 1988). Their premisses are not full grown, but can be revised, denied, changed, and overruled according to the corpus and qualities of the case law technique (Williams 1982: 67-96). Their life and growth, "set in motion by the emotion of surprise" trigger "violent response" (Kevelson 1985: 204), thereby adding mimetic and reproductive elements to the interpretation of the original sign (Mendell 1994: 629, note 25). The intermittent mundus imaginalis of judicial decisions are viewed not only in deduction and induction, but also in half-glimpsed abduction.

Decision law is a legal response to a claim, a reaction to an action, or a response to an answer. Technically, in the U.S. judges are said to write opinions to justify their decisions or (in English terminology) judgments in courts of law; they write decisions or judgments. The actual written judgments or opinions giving formal(ized) judgments in court are cold files or pieces of official writing in deductive form, kept for recordation in the U.S. judgment-book and English judgment-roll for appeal procedures and otherwise. The prior decisions are mental communications (formal messages) of an authoritative nature according to the size of the audience:

Many commands, orders or warrants are issued directly to one person. The decision in a court case binds the immediate parties - two people, sometimes more - and a small circle of officials who may have to help carry it out. The indirect message, of course, runs to a wider group. Orders, warrants, and commands are usually less important than more general messages - doctrines, laws, principles, or rules. (Friedman 1977: 58) 
The legal burden of proof are directed to Peirce's community, (re)affirming a "proposition whose falsity can never be discovered and $[\ldots]$ contains $[\ldots]$ upon our principle, absolutely no error" $(C P: 5.311)$. The underlying decisions with its abstract deductive contents are preferred as having inductive forms. The inductive forms refer to the case suggesting the provisional (and questionable) intention in the light of judicial policy (William 1982: 97-111). William speaks of dealing with standard and "fringe" meaning, the context and "mischief" rule in the wording, the literal rule and room for differences of opinion, stating that "the literal rule is a rule against using intelligence in understanding language" (William 1982: 105), significantly adding that

Anyone who in ordinary life interpreted words literally, being indifferent to what the speaker or writer meant, would be regarded as a pedant, a mischiefmaker or an idiot. One practical reason for the literal rule is that judges are now deeply afraid of being accused of making political judgments at variance with the purpose of Parliament when it passes the Act. (Williams 1982: 105)

The inductive shapes obey the economic trends and social forces. The judicial meanings support their policy lines and instrument the judge's values. The pressure of this liberal and conservative "scaling" technique (Friedman 1977: 172), pinned on a "scale" of public opinion, is a commonly accepted and socially acknowledged technique in order to end the legal uncertainty and create a degree of order out of chaos (Ricoeur 2000: 127-132).

The abductive background of legal decisions serves as a troublesaver in the coldness of the just solution. The right solution is manysided and may convey different interpretations, both usual and unusual meanings repeated as errors and crude mistakes, and hardly understood as existing power or force working in human reality or "reality". Are there tentative signs of emotive and emotional genres within verdicts and other legal decisions, where personal or ideological intuitions are acknowledged as being more than an open and secret space? Take the case (or maybe the vision) of the judge who decides by his or her feeling, and not by judgment or rationalization, conducted in a scientific and public debate of the "hunch" theory as a powerful feature of judicial reasoning and decisions; see Hutcheson (1929), Wasserstrom (1961), Mendell (1994). Recently, take the "puzzling" pronouncement of Posner (2001) about the presence of 
emotion in law, suggesting Peirce's abduction within legal decisionmaking.

The abductive argumentation is claimed in the judgment pronounced, as opposed to the rationalization by the judge of the processes of his or her mind. After Peirce's death and in the last years of Holmes's life, Judge Joseph C. Hutcheson, Jr. (1879-1973), a friend of Dewey, wrote a playful but spectacular article on "The Judgment Intuitive: The Function of the 'Hunch' on Judicial Reasoning" (1929, see Mendell 1994: 627-629, note 17). In Hutcheson's pejorative words in his negative, even alarmist, essay on the judge's mental connection between question and decision, a few hunches or guesses

[...] were recognized in four kinds of judgments: first the cogative, of and by reflection and logomancy; second, aleatory, of and by the dice; third, intuitive, of and by feeling or "hunching"; and fourth, asisine, of and by an ass; and in that same youthful, scornful way I regarded the last three as only variants of each other, the results of processes all alien to good judges. (Hutcheson 1929: 275-276)

This leaves the intelligent speculation, deciding by feeling not by judgment, open for discussion in Hutcheson's article. Behind the hidden truth in hard cases, the judge "being merely on his way [...] to find the just solution, will follow his hunch wherever it leads him, and when, following it, he meets the right solution face to face" (Hutcheson 1929: 278) and enable him to pronounce his judgment. A hunch is the

[...] tiptoe faculty of the mind which can feel and follow a hunch which makes not only the best gamblers, the best detectives, the best lawyers, the best judges, the materials of whose trades are the most chancey because most human, and, the results of whose activities are for the same reason the most subject to uncertainty and the best attained by approximation, but it is that same faculty which has guided and will continue to open hidden doors. (Hutcheson 1929: 179)

The hidden door is abductive thought, revealing "the soul of the fact" in a "flash of luminous hypothesis" (Hutcheson 1929: 281).

Without mentioning Peirce and Holmes, but briefly naming their theological friend in the law-dominated Metaphysical Club, William James (Hutcheson 1929: 282, Menand 2001: x-xi), Hutcheson characterizes intuition or imagination as a "lucky find" made at "apocalyptic moments" of professional life (Hutcheson 1929: 281). In contra- 
distinction with the deductive and inductive models, the judge perceives abduction as "this sensitiveness to new ideas, this power to cast in ever widening circles to find a fresh scent, instead of standing baying where the track was lost" (Hutcheson 1929: 280). The judge trusts his or her own imaginative response to an idea and takes his knowledge for granted. This article exaggerates the high formality of the judge's status and applying to his mental posture the description of a tricky inventor to "trace the hidden equities of divine reward, and to catch sight through the darkness, of the fateful threads of woven fire which connect error with its retribution" (Hutcheson 1929: 288). Hutcheson's parody may be regarded as an unique combination of both creative and cognitive criticism, entertained with a bit of comic effect.

Hutcheson's mock-aesthetic illusion of 1929, however, prompted a valuable debate of self-expression among U.S. judges themselves. Later examples of the improvement in working practices to discover the truth, not the depleted truth but the real truth of emotion in law, include Richard Wasserstrom's The Judicial Decision: Toward a Theory of Legal Justification (1961: 84-117, part. 89-96). Wasserstrom characterized Hutcheson's intuitive comments as "rather mystical statements of approval" (1961: 184). Wasserstrom defuses the controversial issue of the hunch by suggesting that it involves a dual procedure: a process of justification and a process of discovery (1961: 27). A process of justification has non-intuitive, evidential, and utilitarian grounds specified as a bifurcation of deductive and non-deductive reasoning. For Wasserstrom, deductive reasoning means mechanical reasoning, while non-deductive reasoning means inductive reasoning (not explicitly mentioned by Wasserstrom). The process of discovery seems based on instinct, emotion, and custom - as discussed in Peirce's abductive reasoning used in law. Wasserstrom's two procedures of standard-and-rule are the elements of the "rational behavior" of a legal conclusion, building up the logic of right or wrong decisions (1961: 104-105). The process of discovery is the topic of the "talk about judicial hunches, emotions and personalities" (Wasserstrom 1961: 31) rather than publicizing serious scholarship.

The personal desire to integrate guesses into the decisions raises several points:

To begin with a trivial one: it is probably correct that the judge can select any factors he wishes and determining the characterization of the fact situation 
[...]. A more plausible interpretation of this thesis would construe it as asserting that there are no grounds upon which a given characterization may be criticized in other words, that there is no sense in which a particular classification could be termed "correct" or "incorrect", "reasonable" or "unreasonable". (Wasserstrom 1961: 33, his emphasis)

Deduction is the irrational fallacy (Wasserstrom 1961: 33), judged as a utopian strategy. A positive strategy adopted to solve hard cases with a reasonable classification (Holmes's and Peirce's terminology) suggests that "a judge can extract a ratio decidendi of almost any order of generality from a particular case" (Wasserstrom 1961: 35, his emphasis) in order to judge the "vague and imprecise" (1961: 35) circumstances in the case at hand. The judge uses his or her own intuition to make the meaning fit the court's opinion. This (ab)use of emotional tactics to reach formal reasoning means that "justice means the 'natural', 'individualistic', or 'discretionary' adjudication of each case as it arises" (Wasserstrom 1961: 85). Intuition is, for Wasserstrom, "the most just [decision] for the particular case" (Wasserstrom 1961: 86, Wasserstrom's emphasis).

Wasserstrom is a cautious writer, anxious not to be slaughtered himself. He defines intuition as "broader than ordinary philosophical usage" as "any process by which truth or correctness is directly apprehended" including "emotional apprehension" but excluding the "sense of justice" from a "sense of injustice:" "There may be differences between the two approaches, but for my purposes they can be treated as being essentially similar" (Wasserstrom 1961: 89, his emphasis). This distinction is true to the elements and truth-claim of Peirce's hypothesis of abduction, where in legal terms, decision is "the binding decision of the case" (Wasserstrom 1961: 92). The speculation is hoped to be free from the "biases, partialities, and like peculiarities of the judges who render decisions" (Wasserstrom 1961: 93). The personal decision corresponds to three characteristics:

First, under such procedures there should be certain independent criteria by which the one who makes a decision can evaluate the conclusion reached or the course of action decided upon. [...] The second, and perhaps more significant, requirement is that the justification for any proposal should be submitted to and should be able to withstand public examination. [...] The third requirement $[\ldots]$ stipulates that all the grounds or reasons for the decision be both revealed and evaluated. (Wasserstrom 19671: 94) 
The three characteristics are also relevant for Peirce's abduction with its final "wisdom for the community", the final purpose of the critical inquirers, as discussed above (Wasserstrom 1961: 94). Wasserstrom cites Dewey's writings on the philosophy of law. Dewey's article "Logical method and law" (1924) has thrown a bright light on the topic of the external grounds of the legal conclusions:

Courts no only reach decisions; they expound them, and the exposition must state justifying reasons. [...] Exposition implies that a definitive solution is reached, that the situation is now determinate with respect to its legal implication. Its purpose is to set forth grounds for the decision reached so that it will not appear as an arbitrary dictum, and so that it will indicate a rule for dealing with similar cases in the future. It is highly probable that the need of justifying to others conclusions reached and decisions made has been the chief cause of the origin and development of logical operations in the precise sense; of abstraction, generalization, regard for consistency of implications. It is quite conceivable that if no one had ever had to account to others for his decisions, logical operations would have developed, but men would use exclusively methods of inarticulate intuition and impression, feeling; so that only after considerable experience in accounting for their decisions to others who demanded a reason, or exculpation, and were not satisfied till they got it, did men begin to give an account to themselves of the process of reaching a conclusion in a justified way. However this may be, it is certain that in judicial decisions the only alternative to arbitrary data, accepted by the parties to a controversy only because of the authority of prestige of the judge, is a rational statement which formulates grounds and exposes connecting or logical links. (Dewey 1924: 24 after Wasserstrom 1961: 95; see also Merrell 1994: 577, 624-626 and passim)

Intuitions are "private affairs ... difficult to obtain ... [and] even harder to repeat and thereby verify" (Wasserstrom 1961: 95). The external grounds "blur the divide between fantasy and fact, between wish and ideal" so that Wasserstrom needs to conclude that the "judges who think they have had infallible intuitions of particular justice" (1961: 96) are not to be trusted.

Recently, this tradition of the fallibility of decision-making and the role of emotion in law has been continued by Richard Posner, Chief Judge on the U.S. Court of Appeals for the Seventh Circuit and a distinguished legal scholar (1999, 2001). Originally a student of Holmes's skeptical legal scholarship (1992 and passim) and thereby of Peirce's methods of right thinking, Posner interprets the law as the effect of an economic and moral system. He believes that judges base 
their decisions on guesses and personal ideology, hiding behind a veil of precedent. In The Problems of Moral and Legal Theory (1999), Posner briefly touches on the judges' moral intuitions with respect to the pain of the enforced punishment. What is the difference between three and four years spent in prison? The verdicts are not specific but general and social; they have "no fixed objects" and are "morally neutral" (1999: 38). Moral emotions on "numbers" in severe criminal punishments - one year's probation, six month in jail, ten years in the penitentiary, a \$5,000 fine (Posner 1999: 38) — impose the emotional judgments of the judges, "influenced by experience, information, and imagination" and "disciplined by fact" (Posner 1999: 260).

Posner's Frontiers in Legal Theory (2001) does not mention Hutcheson (1929) and Wasserstrom (1961), but develops his own belief in emotivism, rooted in emotion vs "emotionalism" (2001: 2829). Judges have no access to moral truth, their emotionalist attitude means that they tend to give "undue salience to one feature of the situation and its associated stimulus" (Posner 2001: 228). The legal decision to discern the real circumstances of the case becomes a deviated form of mental, moral or spiritual "blindness", where cognitive feeling regards feeling and emotion is secondary to what we expect of judges: real cognitive thought. Emotionalism depends on the discussed "hard" and "soft" qualities of the object. Take the cruel cases of "cold-blooded crimes", "crimes of passion", "hate crimes" as well as crimes dependent on a psychiatric illness or drug addiction, where the accused claims no legal responsibility or guilt, without "programming" the evidence of extenuating circumstances or a depraved will. According to Posner, "enhanced" punishment, imposed by the judges, would nicely accommodate the pressure of social interest groups or a personal ideology; it creates the barbarous kind of "we-they" thinking that "can lead to barbarous prison conditions, summary justice, and savage punishments" (2001: 235, 240). The emotional distress - transfigured by the direct affects of passion, fellow feeling and empathy — becomes "one-sided, short-sighted, sentimental" penal practices (Posner 2001: 234, 248). Translated into Peirce's semiotic terminology, it becomes raw emotion which generates false "degenerate signs". Degeneracy displays no token for regeneration into logical valid reasoning (as discussed in customary law, see Gorlée 1990, 2004: 119, 136, 183). 
In dealing with the role of emotion in law, Posner (2001: 244-245 and 1988: 101-110) mentions William Shakespeare's moralisticethical play, Measure for Measure (performed in 1604, first printed in 1623 ) in which he wrestles with the solidarity with vice and the "measure" of punishment. The title Measure for Measure comes from Saint Matthew's account of Christ's Sermon on the Mount: "with what measure ye mete, it shall be measured to you again" (Matthew 7: 2 ) and alerts the reader and spectator to the heated power struggle for justice, experienced in the judges' conscience. In Shakespeare's tragicomedy, the virtuous heroine, Isabella, expresses what is morally and ethically good and bad, and in-between where good and bad mingle: "Ignominy in ransom and free pardon / Are of two houses lawful mercy / Is nothing kin to foul redemption" (1987: 800) exclaiming "O perilous mouths / bear in them one and the selfsame tongue / Either of condemnation or approof, / Bidding the law make curtsy to their will, / Hooking both right and wrong to th' appetite, / To follow as it draws" (Shakespeare 1987: 800). Law is rooted in the secret places in the soul, knocked or seeked or asked without committing errors in the emotional distance. Isabella turns the world upside down, reversing the moral maxims and devices of male judges who think that the purpose of life is to "get on" in strong formalism.

The temperaments of Posner's male and female conceptions of law (1988: 108), felt by judges, semiotically called "hot" and "cold" morality, create a moral space for the hidden pitfalls of judicial temperaments (Gorlée 2004: 210-211). Posner writes that in Measure for Measure, the legal terms

$[\ldots]$ suggest ways of minimizing the human factor, minimizing discretion, and maximizing "ruledness" or "legalism". The emphasis is on professionalism, logic, strict rules, sharp distinctions, positive law, and "hard "cases (meaning, not as it has come to means, cases that are difficult, but cases that reach hard results, showing that head and heart are firmly separated); on abstracting from the specific circumstances of a case, from the tug of emotion, and from the personalities of the disputants. (Posner 1988: 107)

This passage is a mixture of the three modes of reasoning: deductioninduction-abduction. The judge, "though [he] errs like others" (Shakespeare 1987: 797), still appears to trust his own forceful energy and boundless pride, but both qualities seem to be disconnected from their basis in pure emotionalism. The judge produces strong, if in the long 
run powerless, and fallible "quasi-signs", relying in his art and craft. Peirce trusted his own "assurance of Instinct; assurance of Experience; assurance of Form" ( $C P:$ 8.374). But one can never be "cocksure" (Peirce's key term) of a feeling, belief, or persuasion, as Peirce assured in his theory of fallibilism (Gorlée 2004: 211 and passim). Peirce adopted his maxim of the force of the community, "Truth crushed to earth shall rise again" $(C P: 5.408=W: 3: 274)$.

Posner has a strong appeal to Peirce's pragmatic thought and its reasoning of cases of doubt and his semiosic (in)determinacy giving a tension with legal formalism. Posner only briefly mentions Peirce's abduction as a "mysterious process" (1990: 105) and states that "Peirce may have been on the right track in suggesting that we are able to choose promising hypotheses to test because of our minds, being themselves the products of nature, have an intuitive grasp of the principle" (1990: 116 note). Concerning the future of this inquiry, Uusitalo's article (1991) would suggest an abductive strain in our legal thinking, related to the reflexive rationality. Let us expect further clarification of the subject of abduction by other semiological defenders.

\title{
Abductive flashes and glimpses
}

In his pragmatistic article "The path of law" (1897), Holmes argued that

\begin{abstract}
When we study law we are not studying a mystery but a well known profession. We are studying what we shall want in order to appear before judges, or to advise people in such a way as to keep them out of court. The reason why it is a profession, why people will pay lawyers to argue for them or to advise them, is that in societies like ours the commance of the public force is intrusted to the judges in certain cases, and the whole power of the state will be put forth, if necessary, to carry out their judgments and decrees. People want to know under what circumstances and how far they will run the risk of coming against what is much stronger than themselves, and hence it becomes a business to find out when this danger is to be feared. The Object of our study, then, is prediction, the prediction of the incidence of the public force through the instrumentality of the courts. (Holmes 1897: 457)
\end{abstract}

To "demystify" the fearful body of decisions of judges, I demonstrated the salience of Peirce's three-step semiotics to the understanding of the ridigity and flexibity of the systems of law. Our 
modern, inductive patters of thought have made us concentrate inescapably upon reaching the deductive universe as the only object we can claim to reach. Legal activity is not entirely logical, it has strong links to personal beliefs and interpersonal communication, introducing abductive vagueness and slippery creativity in forms of national and international judicial reasoning. In situations of conflict and dispute, we fully realize that the legal norm is not just valid logic, but a variety of judgments variously linked to Peirce's three categories, limiting and expanding the utilization of the law. Judicial decisions is not founded on inmutable abstract principles, but revealed the intermittent vision, seen in flashes and glimpses, of backward reasoning: abduction. This article revealed some of the semio-logical sources of this pia fraus, translated as pious frauds, "a symbol not a sign of justice" (Boasson 1966: 68-69).

\section{References}

Bernstein, Richard J. 1975. Charles Sanders Peirce and The Nation. In: Peirce, Charles Sanders, Contributions to The Nation, 4 vols. (Ketner, Kenneth Laine; Cook, James Edward, eds.) Lubbock: Texas Tech Press, 1: 15-22.

Boasson, Charles 1966. The Use of Logic in Legal Reasoning. (Mededelingen der Koninklijke Nederlandse Akademie van Wetenschappen 29.3.) Amsterdam: Noord-Hollandse Uitgevers Maatschappij.

Dewey, John 1924. Logical method and law. Cornell Law Quarterly 10: 17-27.

Fisch, Max H. 1986a. Introduction. In: Peirce, Charles Sanders (1986) Writings of Charles S. Peirce: A Chronological Edition. 6 vols. (Peirce Edition Project, eds.) Bloomington: Indiana University Press, 3: xxi-xxxvii.

- 1986b. Justice Holmes, the prediction theory of law, and pragmatism. In: Ketner, Kenneth Laine; Kloesel Christian J. W. (eds.), Peirce, Semeiotic, and Pragmatism: Essays by Max H. Fisch. Bloomington: Indiana University Press, 6-18.

Friedman, Lawrence M. 1977. The Legal System: A Social Science Perspective. 2nd ed. New York: Russell Sage Foundation.

Garner, Bryan A. 1987. A Dictionary of Modern Legal Usage. New York: Oxford University Press.

- (ed. in chief) 1999. Black's Law Dictionary. 7th ed. St. Paul: West Group. [Intext references are to Black's, followed by page numbers.]

Gorlée, Dinda L. 1990. Degeneracy: A reading of Peirce's writing. Semiotica 81(1/2): 71-79.

- 1994. Semiotics and the Problem of Translation: With Special Reference to the Semiotics of Charles S. Peirce. (Approaches to Translation Studies 12.) Amsterdam: Rodopi. 
- 1996. A eureka procedure: Pragmatic discovery in translation. S: European Journal for Semiotic Studies 8(2/3): 241-269.

- 1999. Legal drama: A semiotic approach. In: Santaella, Lucia; Machado, Irene (eds.), Face: Revista de Semiotica e Comunicação. Special issue: Caos e ordem na mídia, cultura e sociedade. São Paulo: PUC, 246-256.

- 2000. Der abduktive Ansatz in Übersetzungspraxis und Übersetzungsforschung. In: Wirth, Uwe (ed.), Die Welt als Zeichen und Hypothese Perspektiven des semiotischen Pragmatismus von Charles Sanders Peirce. (Taschenbuch Wissenschaft 1479.) Frankfurt am Main: Suhrkamp, 158-180.

- 2004. On Translating Signs: Exploring Text and Semio-Translation. (Approaches to Translation Studies 24.) Amsterdam: Rodopi.

Holmes, Oliver Wendell 1897. The path of the law. Harvard Law Review 10(8): 457-478.

- 1963. The Common Law. (Howe, Mark DeWolfe, ed.) Cambridge: Belknap Press of Harvard University Press.

Hutcheson, Joseph C. Jr., 1929. The judgment intuitive: The function of the 'hunch' in judicial reasoning. Cornell Law Quarterly 14: 272-288.

Kevelson, Roberta 1982. Peirce's dialogism, continuous predicate, and legal reasoning. Transactions of the Charles S. Peirce Society 18(2): 159-176.

- 1985. Riddles, legal decisions, and Peirce's existential graphs. Semiotica 57(3/4): 197-223.

- 1986. Law. In: Sebeok, Thomas A. (ed.), Encyclopedic Dictionary of Semiotics, vol. 1. (Approaches to Semiotics 73.) Berlin: Mouton de Gruyter, 438-443.

- 1988. The Law as a System of Signs. New York: Plenum.

- 1990. Peirce, Paradox, Praxis. Berlin: Mouton de Gruyer.

- (ed.) 1991. Peirce and Law: Issues in Pragmaticism, Legal Realism and Semiotics. (Semiotics and the Human Sciences 1.) New York: Peter Lang.

- 1993. Some meanings of the idea of human rights. International Journal of the Semiotics of Law 6(16): 71-88.

Lempert, Richard 1988. The autonomy of law: Two visions compared. In: Teubner, Gunther (ed.), Autopoietic Law: A New Approach to Law and Society. Berlin: Walter de Gruyter, 152-190.

Menand, Louis 2001. The Metaphysical Club. New York: Farrar, Straus and Giroux.

Mendell, Mark 1994. Dewey and the logic of legal reasoning. Transactions of the Charles S. Peirce Society 30(3): 575-635.

Mertz, Elizabeth; Weissbourd, Bernard 1985. Legal ideology and linguistic theory: Variability and its limits. In: Mertz, Elizabeth; Parmentier, Richard J. (eds.), Semiotic Mediation: Sociocultural and Psychological Perspectives. (Language, Thought, and Culture: Advances in the Study of Cognition.) Orlando: Academic Press, 261-285.

Millar, James 1975. Holmes, Peirce and legal pragmatism. Yale Law Journal 84: $1123-1140$.

Peirce, Charles Sanders (1931-1966). Collected Papers of Charles Sanders Peirce. (Hartshorne, Charles; Weiss, Paul; Burks, Arthur W., eds.) 8 vols. 
Cambridge: Belknap Press of Harvard University Press. [In-text references are to $C P$, followed by volume and paragraph numbers.]

- 1975-1987. Contributions to The Nation. (Ketner, Kenneth Laine; Cook, James Edward, eds.) 4 vols. Lubbock: Texas Tech Press. [In-text references are to $C T N$, followed by volume and page numbers.]

- 1976. The New Elements of Mathematics by Charles S. Peirce. (Eisele, Carolyn, ed.) 4 vols. The Hague: Mouton. [In-text references are to NEM, followed by volume and page numbers.]

- 1977. Semiotics and Significs: The Correspondence between Charles S. Peirce and Victoria Lady Welby. (Hardwick, Charles S., ed.) Bloomington: Indiana University Press. [In-text references are to $P W$, followed by page numbers.]

- 1982-2000. Writings of Charles S. Peirce: A Chronological Edition. (Peirce Edition Project, eds.) 6 vols. Bloomington: Indiana University Press [In-text references are to $W$, followed by volume and page numbers.]

Pohlman, H. L. 1984. Justice Oliver Wendell Holmes and Utilitarian Jurisprudence. Cambridge: Harvard University Press.

Posner, Richard A. 1988. Law and Literature: A Misunderstood Relation. Cambridge: Harvard University Press.

- 1990. The Problems of Jurisprudence. Cambridge: Harvard University Press.

- (ed.) 1992. The Essential Holmes: Selections from the Letters, Speeches, Judicial Opinions, and Other Writings of Oliver Wendell Holmes, Jr. Chicago: The University of Chicago Press.

- 1999. The Problematics of Moral and Legal Theory. Cambridge: The Belknap Press of Harvard University Press.

- 2001. Frontiers of Legal Theory. Cambridge: Harvard University Press.

Ransdell, Joseph 1986. Peirce, Charles Sanders (1839-1914). In: Sebeok, Thomas A. (ed.), Encyclopedic Dictionary of Semiotics. (Approaches to Semiotics 73.) 3 vols. Berlin: Mouton de Gruyter, 2: 673-695.

Rescher, Nicholas 1978. Peirce's Philosophy of Science: Critical Studies in His Theory of Induction and Scientific Method. Notre Dame: Notre Dame Press.

Ricoeur, Paul 2000. The Just. (Pellauer, David, trans.) Chicago: The University of Chicago Press. [French original: Le Juste. Paris: Éditions Esprit, 1995.]

Rottleuthner, Hubert 1988. Biological metaphors in legal thought. In: Teubner, Gunther (ed.), Autopoietic Law: A New Approach to Law and Society. Berlin: Walter de Gruyter, 97-127.

Saussure, Ferdinand de 1959. Course in General Linguistics. (Bally, Charles; Sechehaye, Albert, eds.) New York: Philosophical Library.

Schwartz, Bernard 1993. A History of the Supreme Court. New York: Oxford University Press.

Shakespeare, William 1987. The Complete Oxford Shakespeare (Wells, Stanley; Taylor, Gary, eds.) 3 vols. Oxford: Oxford University Press.

Uusitalo, Jyrji 1991. Abduction, legal reasoning, and reflexive law. In: Kevelson, Roberta (ed.), Peirce and Law: Issues in Pragmatism, Legal Realism, and Semiotics. (Semiotics and the Human Sciences 1.) New York: Peter Lang, $163-185$. 
Valauri, John T. 1991. Peirce and Holmes. In: Kevelson, Roberta (ed.), Peirce and Law: Issues in Pragmatism, Legal Realism, and Semiotics. (Semiotics and the Human Sciences 1.) New York: Peter Lang, 187-201.

Wasserstrom, Richard A. 1961. The Judicial Decision: Toward a Theory of Legal Justification. Stanford: Stanford University Press.

Weston, Martin 1991. An English Reader's Guide to the French Legal System. New York: Berg Publishers.

Williams, Glanville 1982 [1945]. Learning the Law. 11th ed. London: Stevens and Sons, Sweet \& Maxwell.

\section{Подсказки и догадки: правовые формы семио-логической аргументации}

Юридическая семиотика является быстроразвивающимся подразделом общей семиотики. Трехступенчатые принципы семиотической логики Пирса представляют собой три ключевые категории Первичности, Вторичности и Третичности, основанные на противоположенных методах логики: дедукции, индукции и открытой Пирсом абдукции. Ни дедукция, ни абдукция не могут претендовать на истинность больше, чем дедукция. В противоположность правовой системе, абдукция имеет место быть в интуитивных умозаключениях, которые касаются возможности т.н. обратной аргументации.

Правовые культуры континентального права характеризуются установкой на абстрактно-дедуктивный подход, который диктуется писаным правом, в то время как фактическая хрупкость системы англо-американского права, чьи судебные решения и прецеденты опираются на индукцию, переносит свои обычаи в моральное пространство и время. Правовые системы так называемого “обычного" права предпочитают абдуктивные понятия: авторитетные мнения, убеждения и утверждения в этой системе подняты на уровень юридически действительной аргументации. Юридическое принятие решений в англо-американском праве характеризуется как принятие решений с абдуктивными оттенками.

\section{Vihjed ja oletused: semio-loogikalise argumentatsiooni õiguslikud vormid}

Juriidiline semiootika on üldsemiootika kiiresti arenev allharu. Peirce'i semiootilise loogika kolmeastmelised põhimõtted kujutavad endast kolme võtmekategooriat (esmasus, teisesus, kolmasus), mis põhinevad vastavatel 
loogika meetoditel: deduktsioonil, induktsioonil ja Peirce'i avastatud abduktsioonil. Ei deduktsioon ega ka abduktsioon ei saa pretendeerida tõesusele rohkem kui induktsioon. Vastupidiselt õigussüsteemile on abduktsioon omal kohal intuitiivsetes järeldustes, mis puudutavad nn tagasimineva argumentatsiooni võimalust.

Kontinentaalõigusruumi kultuure iseloomustab suunitlus deduktiivabstraktsele lähenemisele, mida dikteerib kirjutatud õigus, samas kui angloameerika õigussüsteemi faktiline haprus, kus kohtulahendid ja kohtupretsedendid tuginevad induktsioonil, orienteerub harjumuslikult moraali aegruumile. Nn "tavaõiguse" juriidilised süsteemid eelistavad abduktiivseid mõisteid: autoriteetsed arvamused, veendumused ja väited on selles süsteemis tõstetud tegeliku juriidilise argumentatsiooni staatusesse. Juriidiliste otsuste vastuvõttu anglo-ameerika õiguses iseloomustab abduktiivsete varjunditega otsuste vastuvõtt. 